scientific and technical journals in Great Britain and in America, the author should be able to improve this bibliography in a later edition : the opportunity might then also be taken of adding a subject index to the name index which is given at the end of the present book, although the detailed nature of the contents virtually forms a subject index.

\section{R. L. SMITH-Rose}

\section{MODERN CARBOHYDRATE CHEMISTRY}

\section{Advances in Carbohydrate Chemistry}

Edited by W. W. Pigman and M. L. Wolfrom (Associate Editor for the British Isles: Stanley Peat.) Vol. 2. Pp. xiv + 323. (New York : Academic Press, Inc.; London: H. K. Lewis and Co., Ltd., 1946.) 6.60 dollars.

$\mathrm{T}$ HIS volume by no means suffers in comparison with the first in this series (see Nature 157, 676; 1946), and represents a valuable collection of articles setting out the state of knowledge of the subjects selected up to about the end of 1945 , the number of references dated 1946 amounting only to six. The choice of subjects is suitably wide, and the articles on anhydro sugars, the analogues of ascorbic acid, the chemistry of mucopolysaccharides and mucoproteins, bacterial polysaccharides and the chemistry of pectic materials are outstandingly good.

In common with the reviewer of Volume 1, I think it is unfortunate that in a publication of this kind detailed experimental work should be included, for great difficulties are likely to arise, especially for abstractors, if the practice is extended. Although none of the British authors is an offender in this respect, the fact that a member of the editorial board has included experimental details in both volumes gives rise to misgivings for the future.

The first thirty-six pages are devoted to an exhaustive memoir by C. S. Hudson on melezitose and turanose. The history of the chemical investigations is described in great detail, and the evidence proving that turanose is $3-\alpha-d$-glucopyranosyl- $d$-fructose is presented. That experimental evidence is lacking as to whether melezitose contains a sucrose residue is made clear, although many workers will be surprised if this is not the case. The present description of melezitose must, therefore, be $3-[\alpha$ - $d$-glucopyranosyl](?)-d-fructofuranosyl- $\alpha$ - $d$-glucopyranoside.

The account by Standey Peat of the chemistry of the anhydro sugars is noteworthy, and represents a complete survey of this important and fascinating topic. Not only is this article invaluable for reference purposes, but high praise is due for the logical treatment and clarity of style in discussing a complex subject which the author himself has done much to develop.

In the section on ascorbic acid analogues, Fred Smith summarizes the methods of synthesis and properties of these substances, and the hitherto puzzling behaviour of the saccharodilactones is explained by their conversion to reducing enolic forms.

The account by $R$. Lespieau of the synthesis of hexitols and pentitols from unsaturated polyhydric alcohols is decidedly stimulating to those carbohydrate chemists who, like the reviewer, tend to neglect the possibilities of synthesis on account of the vast field of natural products awaiting investigation.

Harry J. Deuel, Jun., and Margaret G. Moorhouse discuss the interrelation of carbohydrate and fat metabolism in an article covering forty-one pages in which nearly two hundred and fifty references are quoted. This article fulfils one of the objects set forth in the Editors' preface to Volume 1, namely, "It may be found desirable to present several reviews of controversial subjects, particularly in those fields undergoing a rapid state of development".

The extraordinary complexities of the mucopolysaccharides and mucoproteins are discussed by Maurice Stacey in a stimulating contribution which should do much to encourage workers to embark upon researches on these substances. The unusual step of introducing exclamation marks into a scientific article presumably indicates the author's impatience with earlier work in this field; it must be remembered, however, that we stand upon the shoulders of the previous generation even if the foothold seems precarious at times.

Taylor H. Evans and the late Harold Hibbert are responsible for an excellent report on bacterial polysaccharides. I was working with Hibbert in Montreal when some of the investigations described were in progress, and it is a great pleasure to see the results collected together, and to recall the enthusiasm of one whose scientific achievements were not, perhaps, sufficiently appreciated in his life-time.

E. L. Hirst and J. K. N. Jones contribute an account of the chemistry of pectic materials which might well serve as a model for future articles, for the temptation to expand by the full discussion of outmoded earlier results is rejected, to the great profit of the reader.

The polyfructosans and difructose anhydrides are described by Emma J. McDonald in a useful survey of a subject the study of which is beset by many experimental difficulties, and a short survey of cellulose ethers of industrial importance by Joseph F. Haskins reminds the reader of the advances made in a more strictly utilitarian field.

Few mistakes were found in this attractive and useful book, and these principally in the initials of the authors in the references. The practice of printing the Christian name in full for women authors, which indeed is highly commendable, has resulted in an apparent sex reversal (references $30,65,103$, in the article on bacterial polysaccharides), as those will observe who studied public health chemistry under Dr. E. Ashley Cooper at Birmingham.

E. G. V. Perctval

\section{X-RAY ANALYSIS AS A TOOL IN CHEMISTRY AND TECHNOLOGY}

\section{Röntgenographisch-analytische Chemie}

Möglichkeiten und Ergebnisse von Untersuchungen mit Röntgeninterferenzen in der Chemie. Von Prof. Dr. E. Brandenberger. (Lehrbücher und Monographien aus dem Gebiete der exakten Wissenschaften, 7.) Pp. 287. (Basel : Verlag Birkhäuser, 1945.) 28.50 Swiss francs.

$\mathrm{N}$ Great Britain, X-ray crystallographers are
abundant, and each can afford to specialize. Some
of us take to hydrocarbons, others only to carbo-
hydrates, and to others again only the fibrous state 